\title{
Protest Communication Ecologies
}

Dan Mercea ${ }^{1}$ (Department of Sociology, City University London, Northampton Square, EC1V $\mathrm{OHB})$

Laura Iannelli (Department of Political Sciences, Communication Sciences and Information Engineering, Universita degli Studi di Sassari)

Brian Loader (Department of Sociology, University of York)

This paper has been accepted for publication in Information, Communication and Society. The final (edited, revised and typeset) version of this paper will be published in Information, Communication and Society, Vol. 19, Issue 3 by Taylor and Francis. All rights reserved. (C) Taylor and Francis, 2015.

The flurry of protests since the turn of the decade has sustained a growth area in the social sciences. The diversity of approaches to the various facets and concerns raised by the collective action of aggrieved groups the world over impresses through multidisciplinarity and the wealth of insights it has generated. This introduction to a special issue of the international journal Information, Communication and Society is an invitation to recover conceptual instruments - such as the ecological trope-that have fallen out of fashion in media and communication studies. We account for their fall from grace and explicate the rationale for seeking to reinsert them into the empirical terrain of interlocking media, communication practices and protest which we aim to both capture with theory and adopt as a starting point for further analytical innovation.

Key words: protest, communication, media, ecology, social media, social movement

Protest communication ecologies is an attempt to pin down a conceptual meeting point for areas of social enquiry addressing increasingly interconnected phenomena. Ecology is a longstanding trope denoting variability. It encapsulates multiple and layered interconnections among component parts and of the latter with their surrounding environment. In information sciences, ecology has been defined as a 'system of people, technologies, practices and values in a local setting' (O'Day, 2000:36). The term 'system' signifies complexity of organisation where technologies imprint on human action which in turn adjusts technologies to local circumstances. Protest, on the other hand, has become a

\footnotetext{
${ }^{1}$ Corresponding author. Email: dan.mercea.1@city.ac.uk
} 
staple albeit non-institutional form of political participation (van Deth, 2014), which is coextensive with a heightened mediation of socio-political intercourse (Keane, 2013).

In this special issue, we contemplate the local variability of protest, its expression, appeal, and ramifications. All the while, we keep sight of the participatory cultures that bridge or separate disparate instances of protest. This opening article provides an outline of these conceptual considerations and relates them to methodological conundrums and apposite reflections instigated by the keynote speakers at the international iCS Symposium Protest Participation in Variable Communication Ecologies and the contributors to the special issue. The speakers were Lance Bennett, Professor of Political Science and Ruddick C. Lawrence Professor of Communication at the University of Washington; Natalie Fenton, Professor of Media and Communications at Goldsmiths College, University of London; Zizi Papacharissi, Professor and Head of the Communication Department at the University of Illinois-Chicago and Beverley Skeggs, Professor of Sociology in the Department of Sociology at Goldsmiths College, University of London.

\section{Media ecologies}

The chief merit of the concept of 'ecology' is that it underscores the need to emplace interconnectedness as its origins, forms, implications and valorisations are pondered. Put differently, an ecology is by definition bounded. Therefore, it is coextensive with many other systems, which stand apart from it in one or more respects. It is this insight that has prompted Olsson (2010) to distinguish between three contemporary media ecologies: the broadcasting, the interactive and the participatory ecology. Retracing his classification back to McLuhan (1964) and the proposition that broadcasting media fundamentally altered human communication and the cultural codes (or grammars) delineating it, Olsson bemoaned the blinding reductionism of medium theoryi.

Having suffered much refinement, the idea that media - technologies and organisations-are pivotal to political interaction, cultural (and economic) production and social interplay continues to hold sway (cf. Castells, 2009). This, although its detractors call attention to the ideological myth or the false consciousness of media centrality (Couldry, 2015), and to the blindsidedness of such media structuralism manifested in the "tendency 
to construe complex social and cultural phenomena as being produced by the inherent logic of a particular communication technology or medium" (Bakardjieva 2015: 985).

If nothing else, the interactive and participatory iterations of the media ecologyfundamentally associated with the two ages of the World Wide Web to date (Web 1.0 and 2.0)-testify to the resilience of the metaphor. Whilst the interactive ecology pertained to an active engagement of audiences with media content, in the participatory ecology audiences were elevated to the position of co-creators of social goods (Benkler, 2006). In their turn, interactive and participatory ecologies spin-off their own mythos of a participatory culture unleashed with expressive, interactive and networked social media.

Criticised for an over-emphasis on the cultural possibilities opened up by social media (Olsson, 2010:100) to the detriment of a realist political economy of media concentration and the near ubiquity of commercial interests vying for dominance on the internet (McChesney, 2013), Henry Jenkins (2006), the artisan of the theory, has described participatory culture as an ideal to struggle for; a political objective of full and equal participation (Jenkins and Carpentier, 2013). Participation, however, has become an imperative stretched across a ballooning array of activities. Poignantly, it has been lamented as all-too-often effusive "whatever communication" of affect online, displacing the circulation of meaningful content (Dean, 2010: 103) and algorithmically predicated on selective exposure to sameness (Webster, 2011:58).

\section{Communication ecology}

Although media ecology seems as the more resonant term (see among others Fuller, 2005; Strate, 2006; Goddard, 2011; Madianou, 2014), communication ecology (Altheide, 1994) pivots on the differentia that it foregrounds the observation of social life to discern its intertwinement with technologies of mediationii. Communication, it is emphasized, is the situated process that underpins social participation. It has been the object of re-inscription with successive media technologies (1994:666). Moreover, communication-mediated or otherwise-has been the process whereby the self-reflexive capacity of a collective subject crystallizes (Melucci, 1989). Its situatedness is relational and interacts with layered 
structures of power whilst remaining open to political action and expression, e.g. with tactical media.

Tactical media pertain to "temporary' reversals of power through appropriative uses of media technologies" initially devised as a counterpoint to broadcasting media (Dieter, 2011:179-181). All too often, broadcasting media have prioritized the arresting dramaturgy of contention at the expense of critical insights into 'the operation of societal power relations' (Gamson et al., 1992:390). Social media, on the other hand, have unwittingly turned into 'organizing agents' of protest (Bennett and Segerberg 2012:752) that, these authors proposed, aid orchestrate and scale up contention. Concerns persist, however, fuelled by the apparent individualisation of both social and political participation (Fenton and Barassi, 2011) at the behest of the owners of the proprietary connectivity services provided by social media (van Dijck, 2013:13). Social media users may have found in these an expedient and convenient way into civic or political causes (Papacharissi, 2010). But a process of deskilling may transpire as individualised users lose the ability to create the collective out of "internal conflict, deliberation and negotiation within the group" (Fenton and Barassi, 2011:189).

Concurrently, the mediation of those individualised linkages is warped by algorithms designed to make user activity salable first and only secondarily meaningful (van Dijck, 2013:14). We would further note that individuals need to be especially resourceful (see Bastos and Mercea, 2015) to fully harness the connectivity of commercial social media (Bennett et al., 2014) and overcome such constrictions on participation as surveillance and algorithmic filtering. The tactical use of commercial media technologies may nonetheless come to pass predicated on a cognizance of the latitude they present (but also the cost they exert) for bolstering protest participation (Postill, 2014) and, increasingly, for sustaining commitment to causes as long as the groups embracing them foster a sense of efficacy and voice among participants (Rohlinger \& Bunnage, 2015).

Notwithstanding, we would add our voice to those of authors who see in the ecological trope (Treré, 2012; Madianou, 2014; Wilken, 2015) a means to ground the empirical verification of the degree and measure the chances (socio-economic, cultural and political) to which the participatory ideal may be attained in the messy interconnections among media, users and their manifold local settings. In their article, Emiliano Treré and 
Alice Mattoni undertake a more comprehensive genealogy of the conceptual device in media studies and chart an original path towards its educated application in social movement research.

\section{Protest, communication and democracy}

The distributed collective expression of contention-for instance in protests that have spilled over from their original locales such as the Arab Spring, the Indignados and the Occupy Movements-testifies to the amplification of the political as defined by Chantal Mouffe (2000). The political is an essential attribute of communication to the extent that it references one of its key purposes, namely to regulate action thereby consigning conflict to the sphere of symbolic exchanges. An exhaustive taxonomy of individual or collective forms of political expression is impracticable, subject to perpetual revision and endlessly assailable with reproofs of its impact on institutional politics (Jenkins and Carpentier, 2013:269) or the media (Gamson et al., 1992; Castells, 2007). Hinting at a line of enquiry that might steer the debate on impact beyond the current scepticism that has helped reify social media, in particular, as a vector for social change, Lance Bennett raised the following question:

'Where did the ideas [at the heart of]...large protests like the Arab Spring or Occupy Wall Street...come from? I think that ideas are important in democracy. Ideas that motivate people. Ideas that give people a guidebook for change and for political organisation...I am interested in where new ideas come from and what the future of democracy looks like when those ideas come along'(24 June 2015).

Striking a cautionary tone regarding the emancipatory potential that has either been pinned on (Howard \& Hussain, 2013) or negated to the participatory ecology of social media (see Halupka, 2014 for a critical review of clicktivism), in her article, Zizi Papacharissi elaborates on her intimation that

'all too often, I think, we are swayed by the virality that social media afford. The speed, the spreadability with which events unfold over social media platforms...and then when change does not follow at the same speed or is not of a political or legislative or systemic nature we are disappointed. And we think that social media 
have no impact but it is not our media that fail us; it is rather our expectations that fail us. Change is gradual... Revolutions may happen over an instance but they do not render impact that is instantaneous' (24 June 2015).

Democracy, one has to remember, is a normative political construct lying in tension with other political regimes, which do not stress the resolution of conflict through communication to the same level that it does (Whitehead, 2002; Mouffe, 2013). Moreover, political cultures by-and-large circumscribed to nation states (Inglehart, 1988:1204) confine the political imaginary or the 'conditions of possibility for the political and politics' (Suzi et al., 2012:5-7). Participatory cultures of self-expression and distributed organisation such as those witnessed in the protest wave unfolding since 2011 (Biekart and Fowler, 2013) have nevertheless occurred in communication ecologies spanning national borders. They have drawn attention to the interaction between local settings-democratic and nondemocratic-and transgressive media practices that query the seemingly static normativity of political cultures.

The Tunisian uprising is a case in point. It is an illustration of the imbrication of discrete media-from an individual's mobile phone camera to social media and satellite television-used tactically and subversively to turn the footage of Mohamed Bouazizi's selfimmolation into a symbolic spark for the popular insurrection that overthrew the country's authoritarian regime (Lim, 2013). The same case testifies to the 'integrated environments of affordances' (Madianou, 2014:667) encased in smart phones and the wider spectrum of autonomy for activists to frame protest (Gitlin, 2003) and to begin to claw back the democratic power to shape their political context (Hay, 1997:50). This is, according to Papacharissi, a 'semantic agency because it is claimed discursively' whilst the power it emanates is 'liminal or of a transient nature' (24 June 2015).

In this issue, and in the spirit of Dahlgren's (2009) exemplary demonstration of how a civic culture articulated in casual political talk informs participation in a growing range of actions bearing directly or indirectly on institutional politics, we grapple with the variability of contentious communication that baits the dominant normativity of democratic politics. The undertaking is at once descriptive and explanatory as it paints a rich canvas for a comparative outlook on protest communication ecologies. To this end, Lorenzo Mosca and Mario Quaranta present their comparative study of non-institutional participation in three 
distinct media and political systems - Italy, Germany and the U.K. Their investigation was based on a felt absence of a juxtaposition between contextual sensitivity and comparative methodology in previous efforts to determine if either political systems, communication ecologies or both bear on non-institutional participation. Their main insight is that patterns of news consumption and social media usage that are fertile for participation remained largely unchanged across the three countries.

Staying on the same level of analysis, we are reminded that democratic institutions have been hollowed out by global capitalism (Couldry, 2010) to the point that stark material inequalities demand a radical redistributive intervention to restore the ability to participate of sizeable social categories such as the unemployed youth pushed deeper into political insignificance by their eroded socio-economic status (Fenton \& Titley, 2015). Young people have responded with vigorous protests 'intensified' with social media (Sloam, 2014) to the precariousness inflicted upon them by the economic downturn and subsequent austerity politics. Ironically, that socio-technological nexus has primarily been the province of 'young, highly-educated, technologically savvy citizens' (2014:218); a finding that makes all the more apparent the timeliness of the above call for social justice. In this issue, Natalie Fenton therefore insists on foregrounding the contextual roots of political contention so as to build an analytical apparatus that is capable of formulating a much needed radical progressive politics that goes beyond a diagnosis of communication dynamics.

All the while, expectations have remained in place for citizens to be dutiful observers of democratic rules embodied in political institutions (Bennett et al., 2009). The latter are, nevertheless, faced with a conspicuous appetite for direct action to effect social change from members of the body politic disenchanted with the politics-as-usual of representative democracy (Dalton, 2008). Protest, however, is at once vilified for its subversiveness and extolled for its vital capacity to turn a mirror onto unresponsive, even unaccountable democratic institutions (Rosanvallon and Goldhammer, 2008). Raising an alarm call, Natalie Fenton evoked the documented (Klein, 2002; della Porta, Peterson and Reiter, 2006:5) readiness of some democratic governments to restrict the protest franchise itself. In her words,

'...[there are] huge efforts now to ever-more criminalise dissent and protest with trade union laws [in the U.K. which] are going to make it almost impossible to have a 
legal strike. So for me, they are the critical issues...[So] how on earth do we create mobilisations to develop a counter-politics that will bring about progressive social change? (24 June 2015)'

Roger Hallam advances a tentative response to this quandary in his article. He illustrates how what he calls the 'I will if you will collective action mechanism' can engender the mobilisation of latent groups who would otherwise be faced with onerous costs to communicate, coordinate and bridge physical distances. The latter may be offset when a critical mass is pre-organised through dedicated pledge-making connectivity services. He posits, nevertheless, that a cultural lag will likely delay the uptake of the mechanism by collective political actors. The example Hallam provides is equally an opportunity to recognize that the communicative component of contemporary protest encompasses not only symbolic exchanges but also the technological architecture which itself constitutes a primary object of contestation.

Historically, a political response to the commodification of computer technologies (Taylor, 2005), hacktivism has highlighted the need to place a technological critique at the heart of contentious politics. Hacktivism has thrown into relief the inextricable materiality of contemporary protest and its communication ecology. It continues to push the boundaries of collective action and organisation (Coleman, 2013a:210) and has actively bolstered embodied protests and social movements such as Occupy (see Coleman, 2013b on the involvement of Anonymous). Hacktivism enlists programming expertise to expose the power relations inherent in media technologies and infrastructures, thereby weaving them into the fabric of contention (Kubitschko, 2015). A call for systematic and critical scholarship rooted in empirical prowess that can unravel the mechanisms whereby Facebook and other social connectivity services devise performative persona is made by Beverley Skeggs in her article. Skeggs urges us to go beyond the radiography of the alienation of users from their input in the communication taking place through connectivity services (Fuchs, 2014), to appreciate the complex personalised ecologies they spin through the tracking of individual browsing; and how the process may impinge on individual as well as collective agency, not least to protest. In the course of the symposium Skeggs advised that,

'we really need to understand how our whole capacity, our subjectivity is becoming monetised. We have lost the big picture in so many ways. We need to understand 
exactly the new varieties and the new forms of capitalism...how they work through us...to turn us into network subjects in the interest of capitalism [and how this] can be refused. I think we need to learn how the networks work. I think we need to learn how monetisation, financialisation, commodification work' (24 June 2015).

\section{Methodological conundrums}

Methodologically, grasping with protest communication ecologies is an exacting task. Recent attention to scale-shifts has been dominated by innovation in the treatment of online big data and the concern with the aggregate-level explication of collective action (Gonzalez-Bailon et al., 2013; Bennett et al., 2014; Bastos et al., 2015; Monterde et al., 2015). Whilst this direction of travel remains fruitful and broad patterns of social action are yet to be exhaustively described and fully appreciated (Burrows and Savage, 2014), implications for democratic norms, social and cultural practices likely come into sharper focus when resituated in local settings and lived experience.

Ethnographic contextualisations of media practices (e.g. of the Occupy Movement, Gerbaudo, 2012; Juris, 2012) have done much to situate (and dispute) general observations into the lived experience of individuals or organisations finding themselves in the thick of collective action. Likewise, survey data have helped to build a wider picture of interlocking media practices and their prevalence among protestors in contexts as varied as Egypt's Tahrir Square Tufekci and Wilson, 2012), the Chilean student uprisings (Valenzula, 2013) or among students in Romania (Burean \& Badescu, 2014). In Zizi Papacharissi's eyes, an emic approach aimed at 'deciphering the impact of social media and understanding, describing in more accurate terms and contextualising the role and the meaning that they have for social movements' (24 June 2015) is yet to bear full fruition. In his remarks, Lance Bennett spoke of closing the seeming analytical gap marking

'the relationship between core activists who are in the camps, who are running the media operations and the crowd, the periphery who are building a public for these protests. My sense is that there are two theoretical camps. One group is looking ethnographically at core activists and another group, which I am more a part of, is looking at the organisational processes in the media crowd. But I think it is time, and it 
will probably take five years to do this, to theorize the relationships all along the way' (24 June 2015).

Both these approaches have to face up to the challenge of the rapid 'rate of change' of media technologies (Karpf, 2012:644) as well as the distinct temporal rhythms marking their usage (Weltevrede et al., 2014). In their paper, Sarah Jackson and Brooke Foucault Welles envisage a redressal of the balance between the analysis of temporal and network dynamics on social media. The two authors contend that social network analysis has been particularly effective at sweeping network topologies to identify elite communicators on social media. The emergence and potential explanations for the rise to prominence of elites are part of a neglected temporal dimension which the two authors rescue as they revisit the \#Ferguson hashtag and evidence the rise of a Twitter counterpublic in the wake of the shooting of Michael Brown, a young African American, by police in the U.S. state of Missouri.

Another enduring challenge in the variable climate we have depicted is how to maintain the ethical standards of empirical research. In this issue, Paul Reilly and Filippo Trevisan advocate a heightened sensitivity to the contextual politics of the research site. They report on a study of the loyalist flag protests in Northern Ireland proposing an ethical stance that comes as closely as possible to future-proofing the welfare of research participants. This would entail minimising the possibility that participants making public comments on social media who are unaware of their involvement in on-going research become identifiable subjects of wider interest-inter alia through online searches of comments reproduced for explanatory purposes-following the publication of research findings.

One final imputation levelled at the study of protest communication ecologies which we would reprise here is the disproportionate interest it has shown in the progressive politics of the left compared to the relative scarcity of sources tapping into the workings of far right groups (notable exceptions are Atton, 2006; Caiani \& Wagemann, 2009; Caiani \& Parenti, 2013). Speaking to the suspicion of an elective affinity, Lance Bennett delineated two research fields demarcated by contrasting social movement cultures (see Williams, 2004): 
'I have spent some time thinking about how we, who are interested in protest and challenger politics could better understand the right and the far right, the antiimmigrant right, the neo-nazi right and others. What I keep coming up against is that the left likes to be transparent, likes to tell you what it is doing, wants you to join their networks and share their governance systems, more or less. But what I find is that when you begin to use the same tools that we use to study the centre-left, to study the centre and the far-right, there is just too much missing... and, of course, if you go in and do ethnographic interviews you could run into some trouble. So I think that getting access to these politics is much trickier... figuring out how to study those ecologies presents a different set of challenges than the ones we are trying to discuss' (24 June 2015).

\section{Conclusion}

These aspects form the broad outlines of the analytical puzzle we have aimed to address with fresh insights into the conditions of possibility for political protest, a weatherglass for the robustness of the democratic project (della Porta, 2013). All along, we take notice of the power differentials and the obstacles for progressive collective action present in existing communication ecologies. It is thus worth reiterating the obvious here, namely that commercial technologies have to first of all be economically viable to be widely available whilst they remain subject to transformations dictated by their market performance (Wilken, 2015). Moreover, their accelerated convergence and the hybrid media practices induced by this tendency expedite unaccountable practices such as blanket surveillance (Webster, 2011; Andrejevic, 2014). Ultimately, we see in protest communication ecologies an expedient for problematising the ideal of full participation, its circumscription by the circumstances and practices of social actors in intricate local settings and the (intelligence and/or economic) value-extraction apparatus native to media technologies and infrastructures.

\section{References}

Altheide, D.L. (1994). An ecology of communication: Toward a mapping of the effective environment. The Sociological Quarterly, 35(4), 665-683. 
Andrejevic, M. (2014). Infoglut, London: Routledge.

Atton, C. (2006). Far-right media on the internet: culture, discourse and power. New Media \& Society, $8(4), 573-587$.

Bakardjieva, M. (2015). Do clouds have politics? Collective actors in social media land. Information, Communication \& Society, 18 (8), 983-990.

Bastos, M.T., Mercea, D. Charpentier, A. (2015). Tweets, tents, and events: The interplay between street protests and social media. Journal of Communication, DOI: 10.1111/jcom.12145.

Bastos, M. T., Mercea, D. (2015). Serial Activists: Political Twitter beyond influentials and the Twittertariat. New Media and Society, DOI 10.1177/1461444815584764.

Benkler, Y. (2006). The Wealth of Networks: How Social Production Transforms Markets and Freedom, New York and London: Yale University Press.

Bennett, W.L., Wells, C. \& Rank, A. (2009). Young citizens and civic learning: two paradigms of citizenship in the digital age. Citizenship Studies, 13 (2): 105-120.

Bennett, W.L., Segerberg, A. (2012). The logic of connective action. Information, Communication \& Society, 15 (5), 739-768.

Bennett, W. L., Segerberg, A. \& Walker, S. (2014). Organization in the crowd: peer production in large-scale networked protests. Information, Communication \& Society, 17 (2), 232-260.

Bennett, W.L. (2015). Roundtable Discussant. iCS Symposium Protest Participation in Variable Communication Ecologies, Alghero: University of Sassari, 24-26 June 2015.

Biekart, K., Fowler, A. (2013). Transforming activism 2010+: Exploring ways and waves. Development and Change, 44(3): 527-546.

Burean, T., Badescu, G. (2014). Voices of discontent: Student protest participation in Romania. Communist and Post-Communist Studies, 47 (3-4), 385-397.

Burrows, R. and Savage, M. (2014). "After the crisis? Big data and the methodological challenges of empirical sociology". Big Data and Society, 1 (1), 1-6.

Caiani, M., Wagemann, C. (2009). Online networks of the Italian and German extreme right. Information, Communication \& Society, 12(1), 66-109.

Caiani, M., Parenti, L. (2013). Extreme right organizations and online politics: A comparative analysis of five Western democracies. In P.G. Nixon, Rawal, R. and D. Mercea (Eds.) Politics and the Internet in Comparative Context, London: Routledge, 135-153.

Castells, M. (2007). Communication, power and counter-power in the network society. International Journal of Communication, 1, 238-266.

Castells, M. (2009). Communication Power, Oxford: Oxford University Press. 
Coleman, E.G. (2013a). The Ethics and Aesthetics of Hacking, Princeton and Oxford: Princeton University Press.

Coleman, E.G. (2013b). Anonymous in Context: The Politics and Power behind the Mask, Waterloo, Ontario: The Centre for International Governance Innovation.

Couldry, N. (2010). Why Voice Matters: Culture and Politics after Neoliberalism, London: Sage.

Couldry, N. (2015). The myth of 'us': Digital networks, political change and the production of collectivity. Information, Communication \& Society, DOI:

10.1080/1369118X.2014.979216.

Dahlgren, P. (2009). Media and Political Engagement: Citizen, Communication and Democracy, Cambridge, New York: Cambridge University Press.

Dalton, R.J. (2008) Citizenship norms and the expansion of political participation. Political Studies, 56(1): 76-98.

Dean, J. (2010). Blog Theory, Cambridge: Polity.

della Porta, D., Peterson, A., Reiter, H. (2006). Policing transnational protest: An introduction. In D. della Porta, A. Peterson, H. Reiter (Eds.) The Policing of Transnational Protest (pp.1-12), Aldershot: Ashgate.

della Porta, D. (2013). Can Democracy Be Saved? Participation, Deliberation and Social Movements, Cambridge: Polity.

Deth, van, J. (2014). A conceptual map of political participation. Acta Politica, 49(3), 349367.

Dieter, M. (2011). Tactical media after control. The Fibreculture Journal, 18, 177-205.

Dijck, van, J. (2013). The Culture of Connectivity. A Critical History of Social Media. Oxford: Oxford University Press.

Fenton, N., Barassi, V. (2011). 'Alternative media and social network sites: the politics of individuation and political participation'. The Communication Review, 14 (3), 179-196.

Fenton, N., Titley, G. (2015). Mourning and longing: Media studies learning to let go of liberal democracy. European Journal of Communication, DOI: $10.1177 / 0267323115597854$.

Fenton, N. (2015). Roundtable Discussant. iCS Symposium Protest Participation in Variable Communication Ecologies, Alghero: University of Sassari, 24-26 June 2015.

Fuchs, C. (2014) Digital Labour and Karl Marx, New York and London: Routledge.

Fuller, M. (2005). Media Ecologies: Materialist Energies in Art and Technoculture, Cambridge, MA: MIT Press. 
Gamson, W.A., Croteau, D., Hoynes, W., Sasson, T. (1992). Media images and the social construction of reality. Annual Review of Sociology, 18, 373-393.

Gerbaudo, P. (2012). Tweets and the Streets: Social Media and Contemporary Activism, London: Pluto Press.

Gitlin, T. (2003). The Whole World is Watching: Mass Media in the Making and Unmaking of the New Left. Berkley, Los Angeles, London: University of California Press.

Goddard, M. (2011). Towards an archaeology of media ecologies: 'Media ecology, political subjectivation and free radios. The Fibreculture Journal, 17, 6-17.

Gonzalez-Bailon, S., Borge-Holthoefer, J. \& Moreno, Y. (2013). Broadcasters and hidden influential in online protest diffusion. American Behavioral Scientist, 57(7), 943-965.

Halupka, M. (2014). Clicktivism: A systematic heuristic. Policy and the Internet, 6(2), 115132.

Hay, C. (1997). Divided by a common language: Political theory and the concept of power. Politics, 17(1), 45-52. 1

Howard, P.N., Hussain, M. M. (2013). Democracy's Fourth Wave? Digital Media and the Arab Spring, Oxford: Oxford University Press.

Inglehart, R. (1988). The renaissance of political culture. The American Political Science Review, 82(4), 1203-1230.

Jenkins, H. (2006). Convergence Culture: Where Old and New Media Collide, New York and London: New York University Press.

Jenkins, H. and Carpentier, N. (2013). Theorizing participatory intensities: A conversation about participation and politics. Convergence, 19(3), 265-283.

Juris J. (2012). Reflections on \#Occupy Everywhere: Social media, public space and emerging logics of aggregation. American Ethnologist, 39 (2): 259-279.

Karpf, D. (2012). Social science research methods in internet time. Information, Communication \& Society, 15(5), 639-661.

Keane, J. (2013). Democracy and Media Decadence, Cambridge: Cambridge University Press.

Klein, N. (2002). Fences and Windows: Dispatches from the Front Lines of the Globalization Debate, London: Flamingo.

Kubitschko, S. (2015). Hackers' media practices: Demonstrating and articulating expertise as interlocking arrangements. Convergence, DOI: 10.1177/1354856515579847.

Lim, M (2013). Framing Bouazizi: White lies, hybrid network, and collective/connective action in the 2010-11 Tunisian uprising. Journalism, 14(7): 921-941.

Madianou, M. (2014). Smartphones as polymedia. Journal of Computer-Mediated Communication, 19(3), 667-680. 
McChesney, R. (2013). Digital Disconnect, New York, London: The New Press.

McLuhan, M. (1964). Understanding Media: The Extensions of Man, London: Routledge.

Melucci, A. (1989) Nomads of the Present: Social Movements and Individual Needs in Contemporary Society, Philadelphia: Temple University Press.

Monterde, A. Calleja-Lopez, A., Aguilera, M., Barandiaran, X.E. and Postill, J. (2015). Multitudinous identities: A qualitative and network analysis of the $15 \mathrm{M}$ collective identity. Information, Communication and Society, 18(8), 930-950.

Mouffe, C. (2000). The Democratic Paradox, London: Verso.

Mouffe, C. (2013). Agonistics, London: Verso.

O’Day, V. (2000). Information ecologies. The Serials Librarian, 38 (1/2), 31-40.

Olsson, T. (2010). From the ecology of broadcasting to the ecology of participation. Nordicom Information, 2-3, 95-104.

Papacharissi, Z. (2010). A Private Sphere: Democracy in A Digital Age, Cambridge: Polity.

Papacharissi, Z. (2015). Roundtable Discussant. iCS Symposium Protest Participation in Variable Communication Ecologies, Alghero: University of Sassari, 24-26 June 2015.

Postill, J. (2014). Freedom technologists and the new protest movements: A theory of protest formulas. Convergence, 20 (3), 402-418.

Rohlinger, D.A., Bunnage, L.A. (2015). Connecting people to politics over time? Internet communication technology and retention in Moveon.org and the Florida Tea Party Movement. Information, Communication \& Society, 18(5): 539-552.

Rosanvallon, P. and Goldhammer, A. (2008). Counter-Democracy. Politics in an Age of Distrust, Cambridge: Cambridge University Press.

Skeggs, B. (2015). Roundtable Discussant. iCS Symposium Protest Participation in Variable Communication Ecologies, Alghero: University of Sassari, 24-26 June 2015.

Sloam, J. (2014). The outraged young: Young Europeans, civic engagement and the new media in a time of crisis. Information, Communication \& Society, 17(2), 217-231.

Strate, L. (2006). Echoes \& Reflections: On Media Ecology as a Field of Study, Cresskill: Hampton Press.

Suzi, A., Smith, J.C.A., Straume, I.S. (2012). Political imaginaries in question. Critical Horizons, 13(1), 5-11.

Taylor, P. A. (2005). From hackers to hacktivists: speedbumps on the global superhighway. New Media and Society, 7(5), 625-646. 
Treré, E. (2012). Social movements as information ecologies: Exploring the coevolution of multiple internet technologies for activism. International Journal of Communication, 6 , 2359-2377.

Tufekci, Z., Wilson, C. (2012). Social media and the decision to participate in political protest: observations from Tahir Square. Journal of Communication, 62 (2): 363-379.

Valenzula, S. (2013) Unpacking the use of social media for protest behavior. The roles of information, opinion expression and activism. American Behavioral Scientist, 57(7), 920942.

Webster, J.G. (2011). The duality of media: A structurational theory of public attention. Communication Theory, 21 (1), 43-66.

Weltevrede, E., Helmond, A, Gerlitz, C. (2014). The politics of real-time: A device perspective on social media platforms and search engines. Theory, Culture \& Society, 31(6), 125-150.

Whitehead, L. (2002). Democratization: Theory and Experience, Oxford: Oxford University Press.

Wilken, R. (2015). Mobile media and ecologies of location. Communication Research and Practice, 1(1), 42-57.

Williams, R. (2004). The cultural contexts of collective action: Constraints, opportunities, and the symbolic life of social movements. In D. A. Snow, S.A. Soule and H. Kriesi (Eds.) The Blackwell Companion to Social Movements, Malden MA, Oxford: Blackwell, 91-115.

\section{Acknowledgments}

The authors are grateful to the University of Sassari for hosting the iCS Symposium Protest Participation in Variable Communication Ecologies

(http://protestcommunicationecologies.com/) and to the Department of Sociology, City University London for its support for the event.

Notes on contributors:

Dan Mercea is Lecturer in the Department of Sociology, City University London. He is the author of Civic Participation in Contentious Politics: The Digital Foreshadowing of Protest (forthcoming, Palgrave).

Laura lannelli is Lecturer in the Department of Political Sciences, Communication Sciences and Information Engineering, University of Sassari. She is the author of Hybrid Politics.

Participation and Communication (forthcoming, Sage).

Brian Loader is Associate-Director of the Science and Technology Studies Unit (SATSU) in the Department of Sociology based at the University of York, UK. 
'The multidisciplinary intellectual tradition building on McLuhan's work (1964) advanced 'media ecology' where media are assumed as environments and environments as media- as an encompassing theoretical framework for grappling with interacting changes in cultural, political, and social organizations.

ii Altheide's (1994) 'ecology of communication' was a conceptual tool for tapping into the relationship between on the one hand, social action and engagement and, on the other, the expanding array of information and communication technologies together with their presumed accompanying logic. 